\title{
SLPI wt Allele
}

National Cancer Institute

\section{Source}

National Cancer Institute. SLPI wt Allele. NCI Thesaurus. Code C51411.

Human SLPI wild-type allele is located within $20 \mathrm{q} 12$ and is approximately $2 \mathrm{~kb}$ in length.

This allele, which encodes antileukoproteinase 1 protein, plays a role in the protection of epithelial tissues from degradation by serine proteases. The SLPI gene is overexpressed in certain types of cancer such as non-small cell lung carcinomas and ovarian carcinomas. 